\title{
The 100 most-cited articles in spinal oncology
}

\author{
Rafael De la Garza-Ramos, MD,,2 Mario Benvenutti-Regato, MD,,2 and Enrique Caro-Osorio, MD1,2 \\ ${ }^{1}$ Tecnológico de Monterrey, School of Medicine and Health Sciences; and ${ }^{2}$ Neurology and Neurosurgery Institute, Centro Médico \\ Zambrano Hellion, TecSalud, Monterrey, Mexico
}

\begin{abstract}
OBJECTIVE The authors' objective was to identify the 100 most-cited research articles in the field of spinal oncology. METHODS The Thomson Reuters Web of Science service was queried for the years 1864-2015 without language restrictions. Articles were sorted in descending order of the number of times they were cited by other studies, and all titles and abstracts were screened to identify the research areas of the top 100 articles. Levels of evidence were assigned on the basis of the North American Spine Society criteria.
\end{abstract}

RESULTS The authors identified the 100 most-cited articles in spinal oncology, which collectively had been cited 20,771 times at the time of this writing. The oldest article on this top 100 list had been published in 1931, and the most recent in 2008; the most prolific decade was the 1990s, with 34 articles on this list having been published during that period. There were 4 studies with Level I evidence, 3 with Level II evidence, 9 with Level III evidence, 70 with Level IV evidence, and 2 with Level $V$ evidence; levels of evidence were not assigned to 12 studies because they were not on therapeutic, prognostic, or diagnostic topics. Thirty-one unique journals contributed to the 100 articles, with the Journal of Neurosurgery contributing most of the articles $(n=25)$. The specialties covered included neurosurgery, orthopedic surgery, neurology, radiation oncology, and pathology. Sixty-seven articles reported clinical outcomes. The most common country of article origin was the United States $(n=62)$, followed by Canada $(n=8)$ and France $(n=7)$. The most common topics were spinal metastases $(n=35)$, intramedullary tumors $(n=18)$, chordoma $(n=17)$, intradural tumors $(n=7)$, vertebroplasty/kyphoplasty $(n=7)$, primary bone tumors $(n=6)$, and others $(n=10)$. One researcher had authored 6 studies on the top 100 list, and 7 authors had 3 studies each on this list.

CONCLUSIONS This study identified the 100 most-cited research articles in the area of spinal oncology. The studies highlighted the multidisciplinary and multimodal nature of spinal tumor management. Recognition of historical articles may guide future spinal oncology research.

http://thejns.org/doi/abs/10.3171/2015.8.SPINE15674

KEY WORDS citation analysis; spinal oncology; spine tumors; spine surgery; bibliometrics

I $\mathrm{N}$ the last decades, spinal oncology has emerged as a separate subspecialty, ${ }^{114}$ reflecting years of research focused on innovative techniques for controlling spinal tumors and managing the pain and pathophysiology arising from these types of cancers ${ }^{84}$ Although management of some diseases may involve few specialists, patients with spinal tumors are usually treated by a multidisciplinary team, including neurosurgeons, orthopedic surgeons, oncologists, radiation oncologists, and neurologists. ${ }^{84}$ Thus, the spinal oncology literature encompasses numerous researchers and countries, specialties, and scientific journals.
Citation analysis is a systematic approach for identifying scientific studies that have a high impact on medicine. This type of analysis has been applied to the literature on general neurosurgery, ${ }^{88}$ orthopedic surgery, ${ }^{67}$ otolaryngology, ${ }^{92}$ urology, ${ }^{64}$ and plastic surgery ${ }^{76}$ Although bibliometric analyses have been performed on spinal surgery as a whole, ${ }^{84}$ as well as on spinal deformity surgery ${ }^{85}$ and lumbar spine surgery, ${ }^{103}$ little is known about the most frequently cited articles specifically related to spinal oncology.

Therefore, the purpose of this study was to identify the 100 most-cited articles on spinal tumors in an effort to identify important contributions to the literature in this field. 


\section{Methods}

The citation indexing service of Thomson Reuters Web of Science was queried. ${ }^{103}$ The search algorithm ([spine OR spinal OR vertebral] AND [tumor OR neoplasm OR cancer OR metastases]) was used in the "Topic" field to identify articles of interest. The following search parameters were used: 1) articles published in the years 18642015, and 2) all languages. The articles retrieved were then sorted in descending order of times cited.

All authors then reviewed the article titles and abstracts to identify the 100 most-cited articles in the area of spinal oncology. Data such as title, authors, author specialty, journal of publication, year of publication, number of citations, article category, and country of origin were recorded. The levels of evidence of the studies were assigned according to therapeutic, prognostic, and diagnostic criteria set by the North American Spine Society (https:// www.spine.org/Portals/0/Documents/ResearchClinical Care/LevelsOfEvidence.pdf). Under these criteria, Level I studies correspond to high-quality randomized controlled trials or systematic reviews of Level I randomized trials; Level II studies correspond to lesser-quality randomized controlled trials, prospective comparative studies, or systematic reviews of Level II studies; Level III studies correspond to case-control studies, retrospective comparative studies, or systematic reviews of Level III studies; Level IV studies correspond to case series; and Level V studies correspond to case reports or expert opinions.

To control for year of publication, a citations per year (CY) index was calculated as follows: $\mathrm{CY}$ index $=$ total number of article citations/years the article has been published (up to 2015).

\section{Results}

Our search algorithm retrieved 157,468 articles, and the top 100 articles on topics related to spinal oncology were identified according to the number of times they were cited by other studies (Table 1). The articles on this top 100 list were cited between 120 (article Nos. 96-100) and 1164 times (top article), and all 100 articles had been collectively cited 20,771 times (with a mean number of citations of 207.7 for each paper). The oldest article on the top 100 list was from 1931, and the most recent from 2008. Ninety-nine articles were written in English, and 1 was written in French. The list comprised 4 Level I evidence studies, 3 Level II evidence studies, 9 Level III evidence studies, 70 Level IV evidence studies, and 2 Level V evidence studies; levels of evidence were not assigned to 12 studies because they were not on therapeutic, prognostic, or diagnostic topics. The top article according to the CY index had been cited 55.2 times per year and was No. 5 on the top 100 list, and the bottom article had been cited 1.61 times per year (No. 72 on the top 100 list). The most prolific decade was the 1990s, with 34 articles on the top 100 list (Table 2).

The top 100 articles were published in 31 different journals, with the Journal of Neurosurgery contributing most studies (i.e., 25 articles), followed by Cancer and Spine, (each having published 12 articles on this list) (Table 3). When we analyzed the articles by study scope and type, 67 were identified as clinical outcome studies (i.e., case series, retrospective cohort studies, prospective studies, and randomized controlled trials), 9 were review articles (including systematic reviews and meta-analyses), 6 were anatomical or pathological studies, 5 were technical notes, 4 were staging or prognostic studies, 4 were radiology studies, 2 were basic science or animal studies, 2 were case reports, and 1 was an epidemiological study. The most common article topics were spinal metastases (n $=35)$, followed by intramedullary tumors $(\mathrm{n}=18)$, chordoma $(n=17)$, intradural tumors $(n=7)$, vertebroplasty or kyphoplasty $(n=7)$, primary bone tumors $(n=6)$, and others $(n=10)$.

The country with the highest number of articles on the top 100 list was the United States $(n=62)$, followed by Canada and France, with 8 and 7 articles each, respectively (Table 4). The author with the largest number of articles on the top 100 list was Fred J. Epstein (sometimes cited as Epstein, F.) with 6 articles, followed by K. D. Harrington (United States), Z. L. Gokaslan (United States), K. Tomita (Japan), N. Kawahara (Japan), S. Boriani (Italy), R. Biagini (Italy), and N. Sundaresan (United States), who each had authored or coauthored 3 articles on this list.

\section{Discussion}

Spinal oncology has exponentially grown during the last decades, currently involves numerous specialties, and is considered by many a distinct subspecialty. ${ }^{114}$ In this study, we sought to identify the most-cited 100 articles in spinal oncology, in an effort to gain insight into the history and future directions of spinal tumor research. Not surprisingly, we found that the top 100 most-cited articles were written by authors in a variety of specialties, including neurosurgery, orthopedic surgery, neurology, pathology, radiology, and radiation oncology. In contrast to other research fields in which most high-impact articles are published in only a few journals, ${ }^{88}$ the most-cited articles pertaining to spinal oncology were published in 31 different journals, also reflecting the multidisciplinary nature of spinal tumor research.

The article that had received the most citations on our top 100 list was an anatomical pathology study by Oscar Vivian Batson, in which the author described a valveless venous system (now known as Batson's plexus) that connects the deep pelvic and thoracic veins to the vertebral venous plexus, a circulation system that most likely is involved in the spread of metastatic disease to the spine. ${ }^{8}$ This article was No. 1 on the list when ranked by the total number of received citations, but it was ranked No. 15 according to the CY index, with 15.52 citations per year since its publication in 1940. The second and third most-cited articles were by French authors, and both studies described vertebroplasty and kyphoplasty, techniques used to treat intractable pain and provide stability to osteoporotic or pathological compression fractures, ${ }^{32,51}$ the description of vertebroplasty for spinal angiomas by $\mathrm{Ga}$ libert and colleagues was the only article on the list in a language other than English (French in this case). These 2 articles were No. 2 and No. 3 also on the CY index list, and their high ranks on both lists support the assertion 


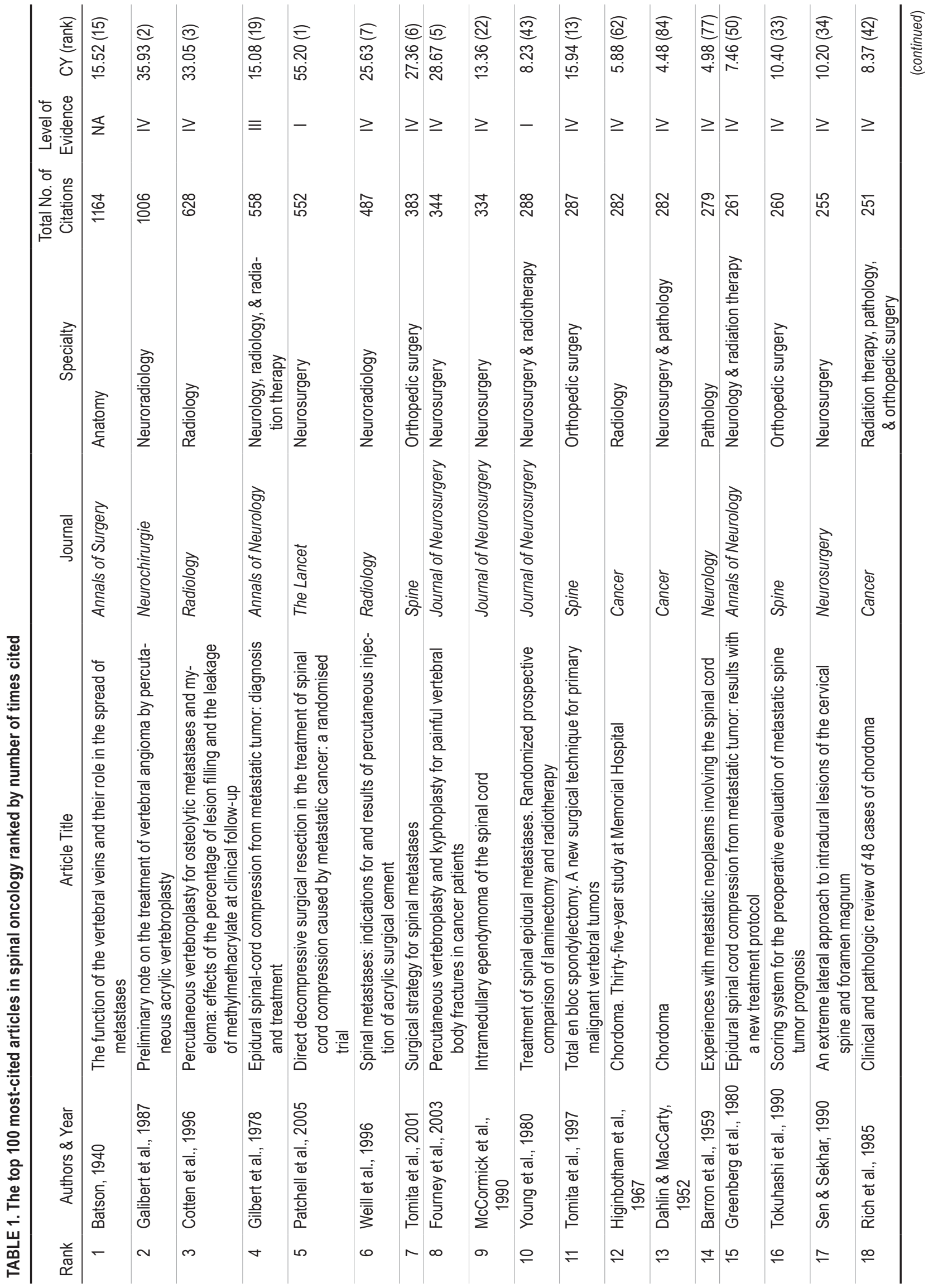




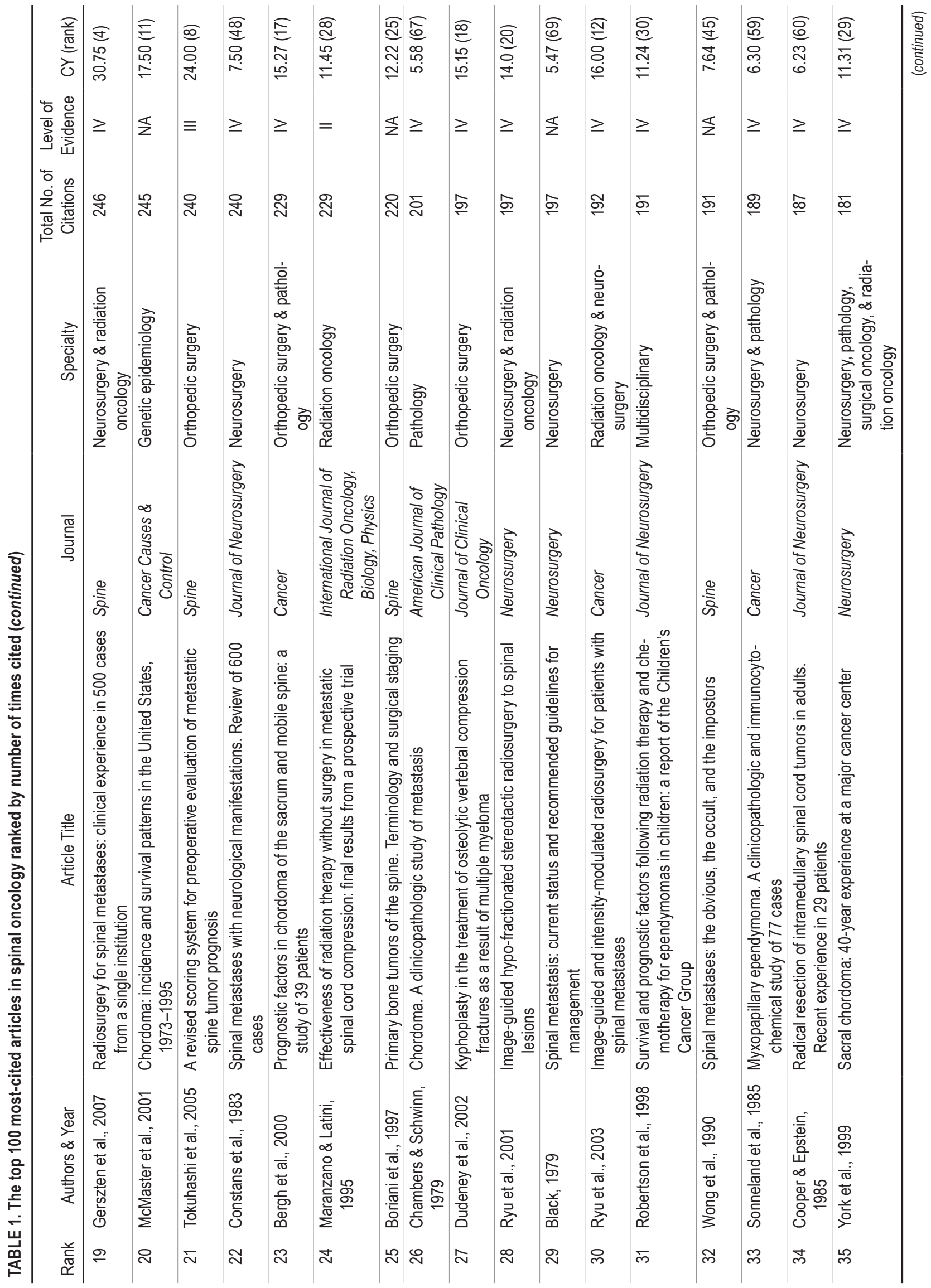




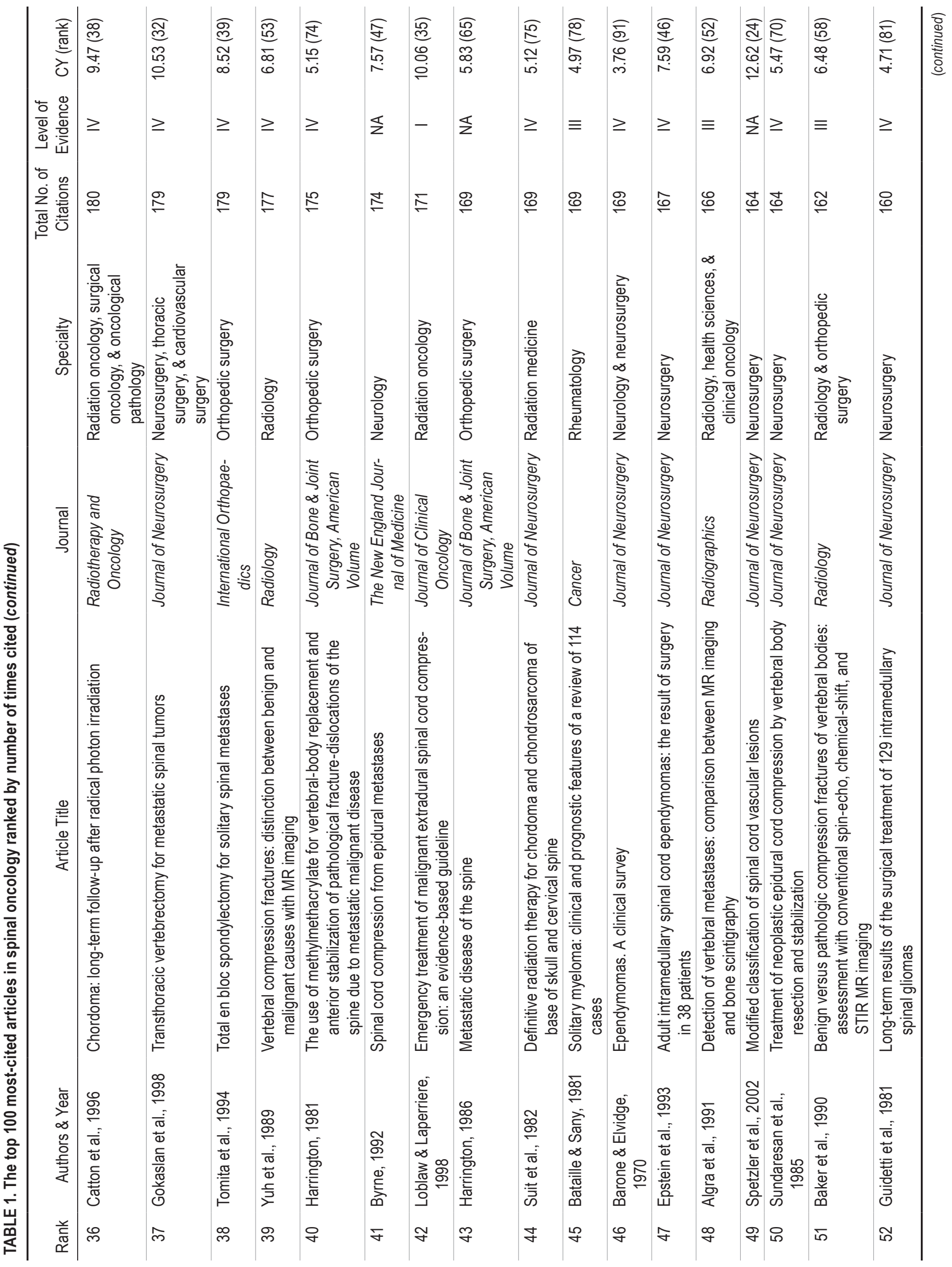




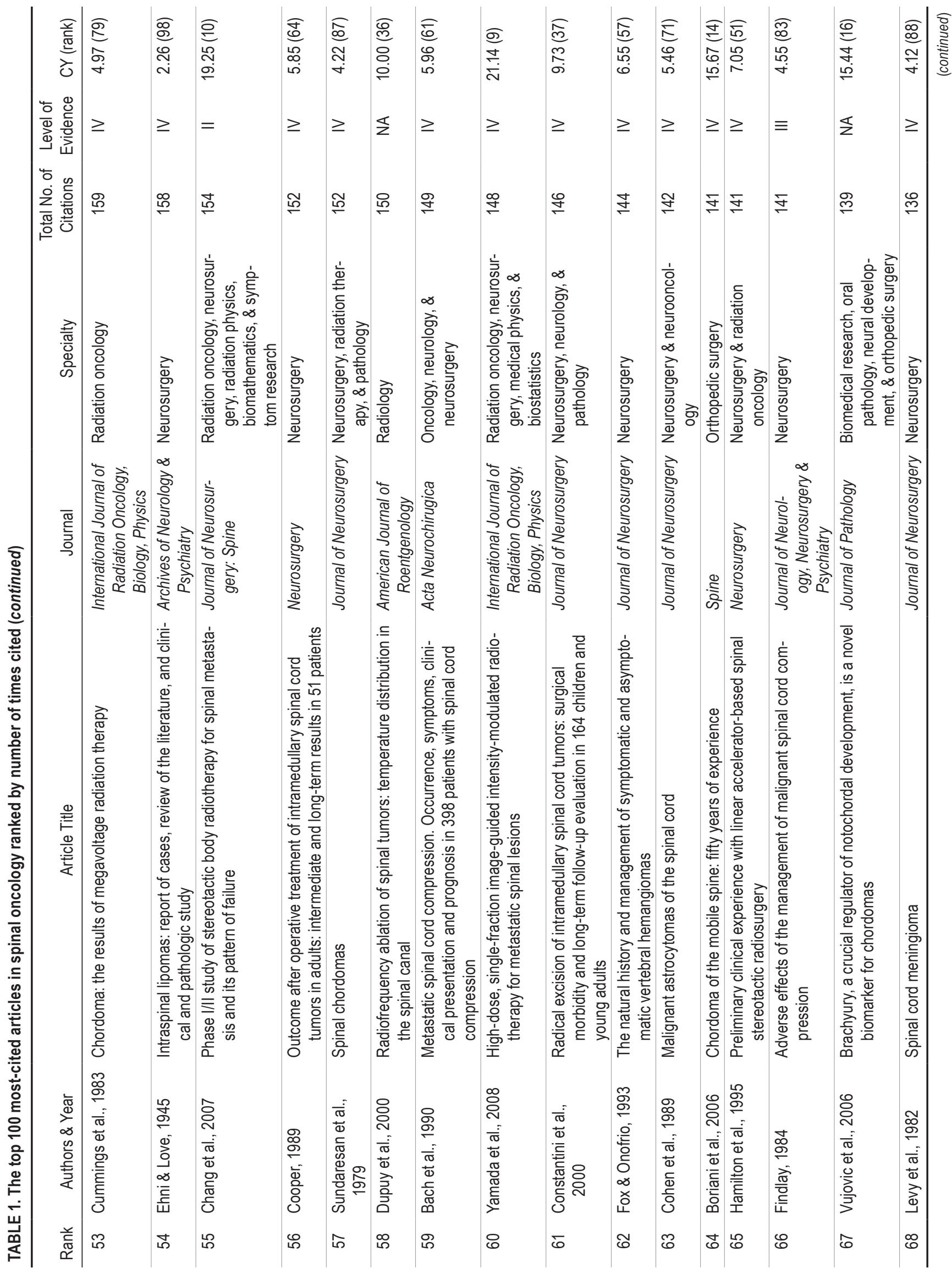




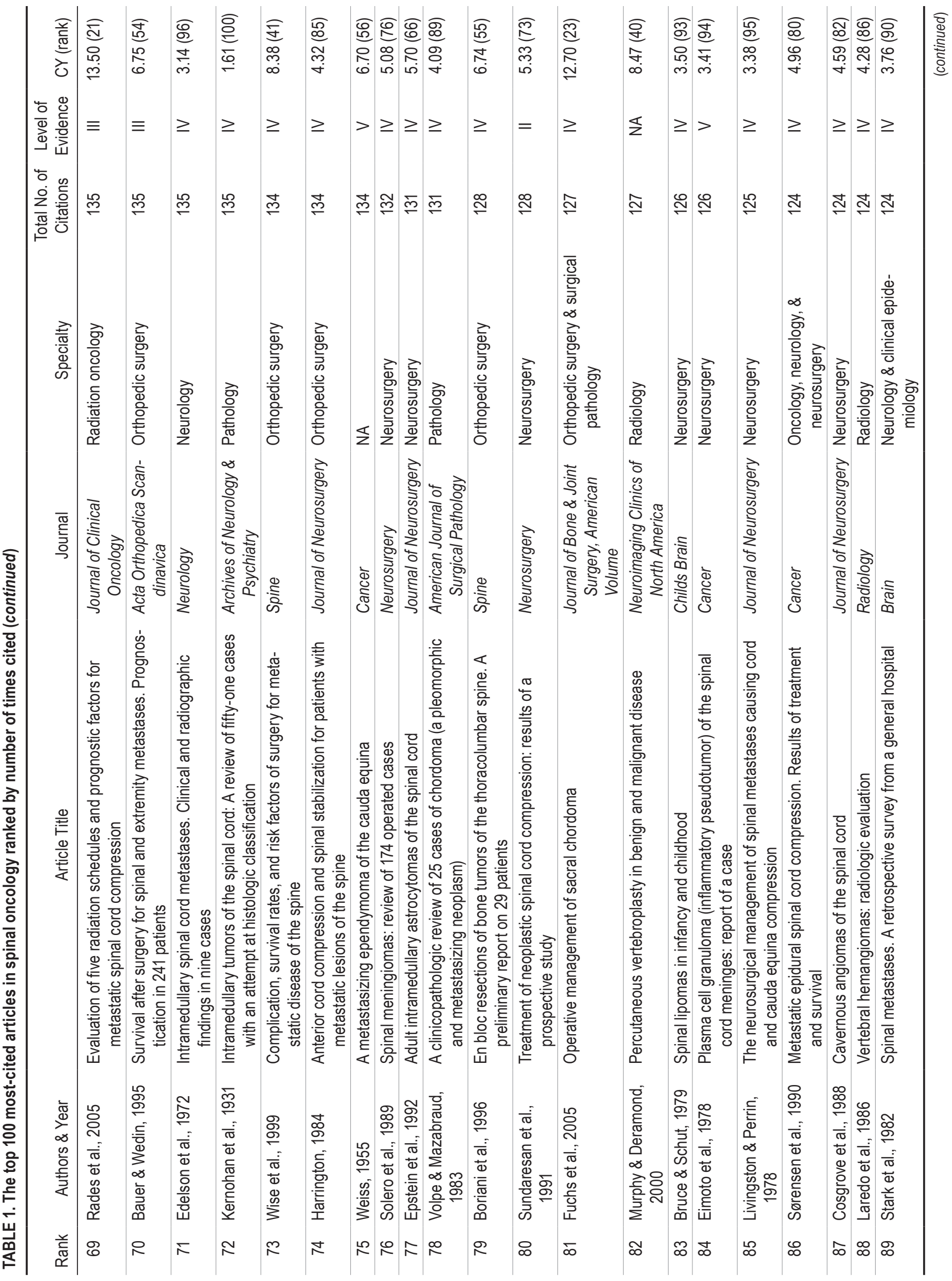




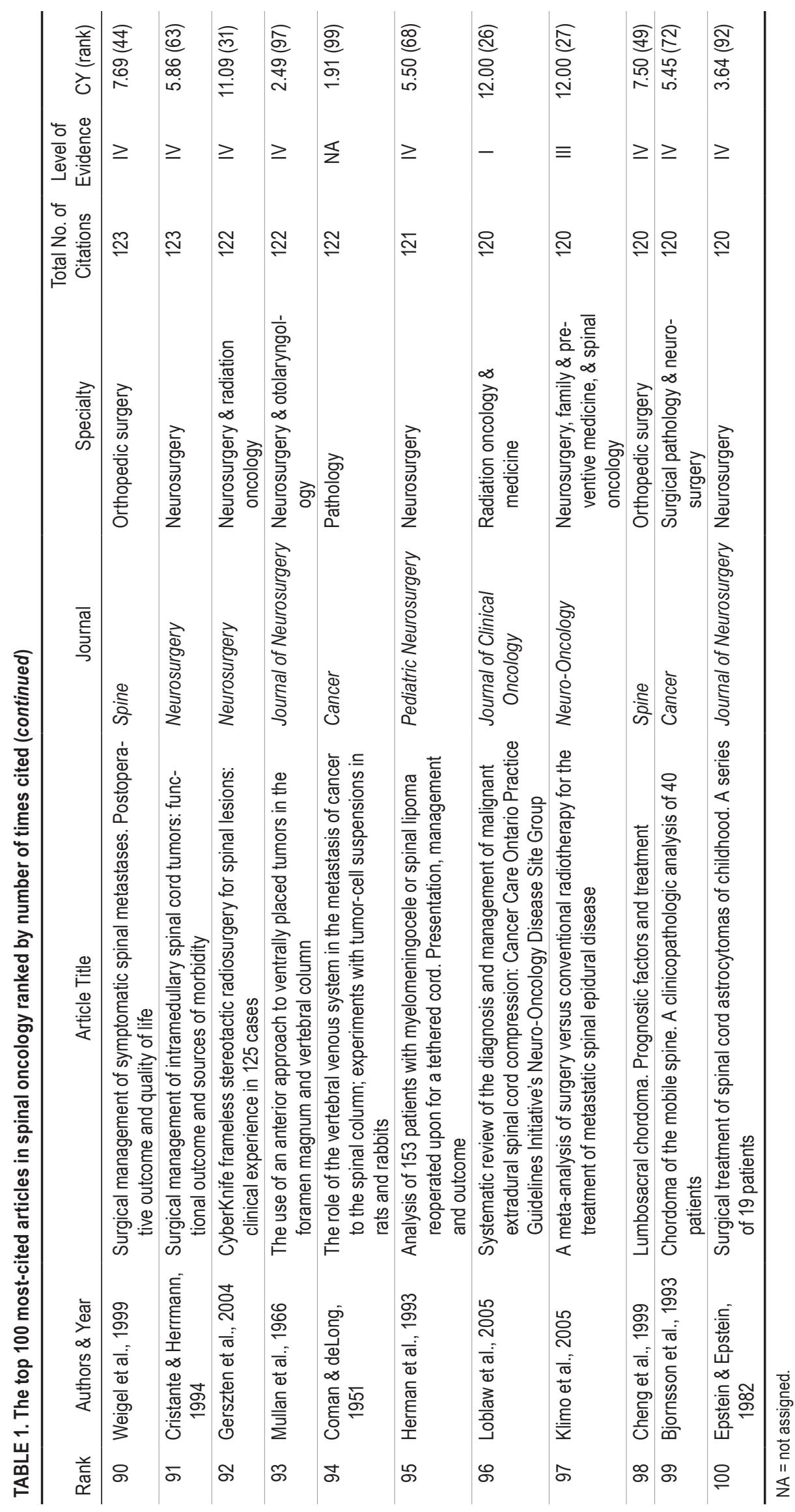


TABLE 2. Decades of publication

\begin{tabular}{cc}
\hline Decade & No. of Articles $(n=100)$ \\
\hline $1930 s$ & 1 \\
\hline $1940 s$ & 2 \\
\hline $1950 s$ & 3 \\
\hline $1960 s$ & 2 \\
\hline $1970 s$ & 9 \\
\hline $1980 s$ & 26 \\
\hline $1990 s$ & 34 \\
\hline $2000 s$ & 23 \\
\hline
\end{tabular}

that both of these studies made a significant impact on the management of pathological compression fractures. Notably, vertebroplasty and kyphoplasty were also the focus of articles that were ranked No. 6 and 8 according to the CY index; in both studies, the authors examined the role of these techniques in the treatment of pathological fractures due to metastatic disease.

Two randomized controlled trials were among the top 10 articles on the top 100 list. A trial by Young et al. published in 1980 investigated the outcomes among patients with metastatic epidural spinal cord compression treated with laminectomy plus radiotherapy versus patients treated with radiotherapy alone; the authors reported that the 2 treatment modalities do not significantly differ in providing pain relief or in improving ambulation or sphincter function. ${ }^{123}$ This trial led to the general belief that outcomes after radiotherapy alone can be equivalent to those after laminectomy without instrumentation. Several years later, Patchell and colleagues reported outcomes of "direct decompressive surgery," in which the pathological compression (most often located anteriorly to the spinal canal) was addressed anteriorly rather than posteriorly via a laminectomy. ${ }^{87}$ The findings of this trial indicated a sig-

TABLE 3. Journals of publication

\begin{tabular}{lc}
\hline \multicolumn{1}{c}{ Journal } & $\begin{array}{c}\text { No. of Articles } \\
(\mathrm{n}=100)\end{array}$ \\
\hline Journal of Neurosurgery* & 25 \\
\hline Cancer & 12 \\
\hline Spine & 12 \\
\hline Neurosurgery & 10 \\
\hline Radiology & 5 \\
\hline Journal of Clinical Oncology & 4 \\
\hline International Journal of Radiation Oncology, Biology, & 3 \\
$\quad$ Physics & 3 \\
\hline Journal of Bone and Joint Surgery, American Volume & 2 \\
\hline Annals of Neurology & 2 \\
\hline Archives of Neurology and Psychiatry & 2 \\
\hline Neurology & 20 \\
\hline Others $\dagger$ &
\end{tabular}

* Also includes Journal of Neurosurgery: Spine, a separate journal that started publication in 1999 ( 1 article on the top 100 list was from JNS: Spine). $\dagger$ These include journals that each contributed 1 article to the top 100 article list.
TABLE 4. Countries of article origin

\begin{tabular}{lc}
\hline Country of Origin & No. of Articles $(\mathrm{n}=100)$ \\
\hline United States & 62 \\
\hline Canada & 8 \\
\hline France & 7 \\
\hline Italy & 6 \\
\hline Japan & 6 \\
\hline Germany & 3 \\
\hline United Kingdom & 3 \\
\hline Denmark & 2 \\
\hline Sweden & 2 \\
\hline Netherlands & 1 \\
\hline
\end{tabular}

nificant treatment difference: patients who underwent direct decompression plus radiotherapy were more likely to walk after treatment and retain the ability to walk longer distances than patients who underwent only radiation. ${ }^{87}$ The study by Patchell et al. had received 552 citations, and was one of the few articles on our top 10 list published in a high-impact factor medical journal (The Lancet). More importantly, however, this article was ranked No. 1 according to the CY index, with 55.2 citations per year since its publication in 2005; this highlights the impact this study had on the management of metastatic epidural spinal cord compression.

Another noteworthy article on our top 10 list was the study by Tomita et al. (from Japan), which was ranked No. 7 on the regular list and No. 6 on the CY index list (with 27.36 citations per year since 2001), and in which the authors described a surgical strategy to approach spinal metastases. ${ }^{112}$ This strategy was based on those reported in several other studies on the top 100 list, mainly the initial report of en bloc spondylectomy for spinal tumors also by Tomita et al. (articles No. 11 and 38) and of the Tokuhashi scoring system (article No. 16). When examining studies by research topic, we found that more than one-third of the articles had a focus on spinal metastases, a disease condition that is the most common type of spinal tumor and observed in $36 \%$ of patients who die of cancer. ${ }^{120}$

The second most common topic among the 100 mostcited articles was intramedullary tumors. Although these tumors account for only $2 \%-4 \%$ of all CNS tumors, ${ }^{95} 18$ articles on the topic of intramedullary tumors were on the top 100 list; these articles focused on outcomes after surgery for ependymoma, cavernous angioma, gliomas, and other tumors. Research focused on chordoma was the third most common area on the top 100 list, with 17 articles (articles No. 12, 13, 18, 20, 23, 26, 35, 36, 44, 53, 57, 64, 67, $78,81,98$, and 99) investigating the genes involved in chordoma, outcomes after surgery or radiation for chordoma, epidemiology of this disease, and other chordoma-related topics. Chordoma has an estimated incidence of 0.08 per 100,000 cases, and is considered the most common primary malignant bone tumor of the sacrum and mobile spine. ${ }^{79}$ Although relatively rare, significant efforts have been directed toward identifying a cure for this disease. Current research has focused on stereotactic body radiotherapy, proton-beam therapy, and novel agents such as nilotinib, 
dasatinib, and imatinib (all tyrosine kinase inhibitors) to treat chordoma patients. ${ }^{17,18}$

The most prolific decade was the 1990s with 34 articles. Eighty-three of the 100 articles were published after 1980; this observation is similar to findings by Steinberger et al. who examined the top 100 articles published on lumbar spine surgery. ${ }^{103}$ The oldest article on our top 100 list was from 1931 by the Irish-American pathologist James Watson Kernohan and colleagues (article No. 72), in which the authors described pathological findings of intramedullary tumors. ${ }^{68}$ The most recent was from 2008 by radiation oncologist Yamada and colleagues (article No. 60), in which the authors examined the effect of high-dose, single-fraction, image-guided, intensity-modulated radiotherapy for local tumor control in patients with metastatic spinal lesions. ${ }^{121}$ This article was No. 60 on the top 100 list and No. 9 according to the CY index (21.14 CY since 2008).

Although authors from the United States contributed most of the studies to the top 100 list (i.e., 62), it is of note that authors from 9 other countries also contributed. When we examined the articles for individual authors, we found that Fred J. Epstein was an author on 6 articles on the list, all focused on intramedullary tumors (articles No. 34, 47, 61, 63, 77, and 100); 7 other authors appeared 3 times each on this list.

According to the level-of-evidence grading, $70 \%$ of the articles were Level IV evidence studies, and only $4 \%$ were high-quality Level I evidence studies. Even though this observation implied scarce high-quality evidence for management of spinal tumors, the challenges of conducting randomized controlled surgical trials must be acknowledged. Such studies require multicenter collaborations, a lot of personnel, large funding, and patients' consent to receiving either an experimental intervention or no intervention. Additionally, we also observed very few Level III evidence studies (case-control studies or retrospective comparative studies), which may be the next step in spinal oncology research. Level III studies are less challenging to conduct than randomized trials, but they allow for multivariable analyses or direct comparison of interventions. We also note that the lower representation of higher-levelevidence studies on the top 100 list does not necessarily mean that these studies have not been frequently conducted-it may simply imply that these types of studies may have not been cited as many times as studies with lower levels of evidence.
To identify temporal trends in spinal tumor treatments, studies reporting on particular techniques were stratified by time published (Table 5). Resection (either subtotal or gross total) was the main topic in articles published in the 1930s and 1940s, and the combination of surgery plus radiation therapy began to be reported in 1950 . This treatment modality then became the mainstay of treatment for spinal tumors up to the 1990s when en bloc resection was shown to achieve superior outcomes compared with intralesional or subtotal resection. Likewise, the introduction of vertebroplasty and kyphoplasty did not happen until the 1980s. Last, frequently cited studies reporting on radiosurgery and photon therapy for spinal tumors were published in the 1990s and 2000s.

As mentioned above, spinal oncology is a dynamic field, and the articles identified in this study reflected that dynamism. Ranging from anatomical pathology studies to randomized controlled trials to systematic reviews, the top 100 most-cited articles focused on topics such as metastatic spinal tumors, primary vertebral column tumors, radiation oncology, surgical techniques, intramedullary tumors, staging and scoring systems, and many other areas. The fact that many distinct specialties and journals were represented among the studies on this list is very interesting and supports the notion that spinal tumors are best treated in a multidisciplinary and multimodal fashion. ${ }^{114}$

Advances in genetics-based treatments, ${ }^{37}$ radiosurgery, ${ }^{17}$ proton-beam therapy, ${ }^{2,86}$ immunotherapy, ${ }^{18}$ and minimally invasive surgery, ${ }^{36,38,70,81}$ among others, will be an important part of the future of spinal oncology. Treatments involving wild-type neurofibromatosis 2 gene insertion, oncolytic viruses, and transfer of gene-silencing ribonucleic acid have all shown promising results in vitro for meningiomas. ${ }^{37}$ Stereotactic body radiotherapy (radiosurgery) has been used as a first-line treatment for metastatic lesions, after failure of conventional radiotherapy, after separation surgery, and as first-line treatment for primary tumors and has shown promising results in each approach. ${ }^{17}$ Recently, proton-beam therapy has gained attention because it can deliver high doses of energy to a small tissue volume; clinical studies have shown high local tumor control and overall patient survival rates, particularly for chordoma. ${ }^{80,86}$

The aforementioned tyrosine kinase inhibitors are currently being investigated for the treatment of chordoma; ${ }^{18}$ other immunotherapeutic agents have also been investigated for metastatic melanoma to the spine. ${ }^{20}$ Last, minimally

TABLE 5. Spinal tumor treatment strategies stratified by decade of publication*

\begin{tabular}{|c|c|c|c|c|c|c|c|c|}
\hline \multirow[b]{2}{*}{ Topic } & \multicolumn{8}{|c|}{ Decade of Publication } \\
\hline & $1930 \mathrm{~s}$ & 1940s & $1950 \mathrm{~s}$ & $1960 \mathrm{~s}$ & $1970 \mathrm{~s}$ & $1980 \mathrm{~s}$ & $1990 \mathrm{~s}$ & $2000 s$ \\
\hline VP/KP & 0 & 0 & 0 & 0 & 0 & 2 & 2 & 3 \\
\hline Surgery & 1 & 1 & 1 & 0 & 3 & 5 & 6 & 1 \\
\hline Surgery + RT & 0 & 0 & 1 & 2 & 4 & 12 & 12 & 4 \\
\hline En bloc resection & 0 & 0 & 0 & 0 & 0 & 0 & 3 & 2 \\
\hline RT & 0 & 0 & 0 & 0 & 0 & 3 & 2 & 0 \\
\hline Radiosurgery & 0 & 0 & 0 & 0 & 0 & 0 & 1 & 6 \\
\hline Photon therapy & 0 & 0 & 0 & 0 & 0 & 0 & 1 & 0 \\
\hline
\end{tabular}

$\mathrm{RT}=$ radiotherapy $\mathrm{VP} / \mathrm{KP}=$ vertebroplasty/kyphoplasty.

* The data represent number of articles. 
invasive surgery has been shown to provide outcomes in terms of neurological recovery similar to outcomes of traditional open surgery for vertebral thoracic metastases causing acute myelopathy ${ }^{81}$ other studies have also examined the role of minimally invasive surgery on intradural tumors. ${ }^{52}$ Although each of these techniques has shown favorable results, patients will most likely have best outcomes when treated by a multidisciplinary team that uses a combination of multimodal strategies.

\section{Limitations}

This study has several limitations. First, some studies have suggested that citation analyses may favor older studies, since these studies had more time to accumulate citations ${ }^{56,96}$ For example, it could be argued that clinical studies such as that by Patchell et al. ${ }^{87}$ on direct decompressive surgery plus radiotherapy have much more clinical "impact" than the anatomical study by Batson, ${ }^{8}$ and yet the latter had more than double the number of citations. For this reason, in an attempt to control for this potential bias, we utilized the CY index. When we ranked the studies according to the CY index, the study by Patchell et al. jumped to No. 1, and the top 10 articles on the CY list included those on topics such as vertebroplasty/ kyphoplasty, radiotherapy, and radiosurgery. Second, although Web of Science has been used for citation analysis, we note that this index does not always include citations from textbooks or journals written in languages other than English. ${ }^{88}$ Third, although we ranked articles by number of citations, we excluded some studies in a subjective manner, and it may be possible that other relevant articles were missed. Last, the number of times an article has been cited does not directly reflect its quality. As shown in this study, most articles were Level IV evidence studies, and only 4 were Level I evidence studies.

\section{Conclusions}

In this study, the 100 most-cited articles in spinal oncology were examined, and important contributions from various authors, specialties, and countries were identified. More than one-third of the research in these articles was focused on spinal metastases, followed by intramedullary tumors and chordoma. The top 100 articles were published in 31 different journals, reflecting the multidisciplinary nature of spinal tumor care. Recognition of important historical contributions to this field may guide future investigations into spinal oncology.

\section{References}

1. Algra PR, Bloem JL, Tissing H, Falke TH, Arndt JW, Verboom LJ: Detection of vertebral metastases: comparison between MR imaging and bone scintigraphy. Radiographics 11:219-232, 1991

2. Amsbaugh MJ, Grosshans DR, McAleer MF, Zhu R, Wages $\mathrm{C}$, Crawford $\mathrm{CN}$, et al: Proton therapy for spinal ependymomas: planning, acute toxicities, and preliminary outcomes. Int J Radiat Oncol Biol Phys 83:1419-1424, 2012

3. Bach F, Larsen BH, Rohde K, Børgesen SE, Gjerris F, Bøge-Rasmussen T, et al: Metastatic spinal cord compression. Occurrence, symptoms, clinical presentations and prognosis in 398 patients with spinal cord compression. Acta Neurochir (Wien) 107:37-43, 1990
4. Baker LL, Goodman SB, Perkash I, Lane B, Enzmann DR: Benign versus pathologic compression fractures of vertebral bodies: assessment with conventional spin-echo, chemicalshift, and STIR MR imaging. Radiology 174:495-502, 1990

5. Barone BM, Elvidge AR: Ependymomas. A clinical survey. J Neurosurg 33:428-438, 1970

6. Barron KD, Hirano A, Araki S, Terry RD: Experiences with metastatic neoplasms involving the spinal cord. Neurology 9:91-106, 1959

7. Bataille R, Sany J: Solitary myeloma: clinical and prognostic features of a review of 114 cases. Cancer 48:845-851, 1981

8. Batson OV: The function of the vertebral veins and their role in the spread of metastases. Ann Surg 112:138-149, 1940

9. Bauer HC, Wedin R: Survival after surgery for spinal and extremity metastases. Prognostication in 241 patients. Acta Orthop Scand 66:143-146, 1995

10. Bergh P, Kindblom LG, Gunterberg B, Remotti F, Ryd W, Meis-Kindblom JM: Prognostic factors in chordoma of the sacrum and mobile spine: a study of 39 patients. Cancer 88:2122-2134, 2000

11. Bjornsson J, Wold LE, Ebersold MJ, Laws ER: Chordoma of the mobile spine. A clinicopathologic analysis of 40 patients. Cancer 71:735-740, 1993

12. Black P: Spinal metastasis: current status and recommended guidelines for management. Neurosurgery 5:726-746, 1979

13. Boriani S, Bandiera S, Biagini R, Bacchini P, Boriani L, Cappuccio M, et al: Chordoma of the mobile spine: fifty years of experience. Spine (Phila Pa 1976) 31:493-503, 2006

14. Boriani S, Biagini R, De Iure F, Bertoni F, Malaguti MC, Di Fiore M, et al: En bloc resections of bone tumors of the thoracolumbar spine. A preliminary report on 29 patients. Spine (Phila Pa 1976) 21:1927-1931, 1996

15. Boriani S, Weinstein JN, Biagini R: Primary bone tumors of the spine. Terminology and surgical staging. Spine (Phila Pa 1976) 22:1036-1044, 1997

16. Bruce DA, Schut L: Spinal lipomas in infancy and childhood. Childs Brain 5:192-203, 1979

17. Bydon M, De la Garza-Ramos R, Bettagowda C, Gokaslan ZL, Sciubba DM: The use of stereotactic radiosurgery for the treatment of spinal axis tumors: a review. Clin Neurol Neurosurg 125:166-172, 2014

18. Bydon M, Papadimitriou K, Witham T, Wolinsky JP, Bydon A, Sciubba D, et al: Novel therapeutic targets in chordoma. Expert Opin Ther Targets 16:1139-1143, 2012

19. Byrne TN: Spinal cord compression from epidural metastases. N Engl J Med 327:614-619, 1992

20. Caruso JP, Cohen-Inbar O, Bilsky MH, Gerszten PC, Sheehan JP: Stereotactic radiosurgery and immunotherapy for metastatic spinal melanoma. Neurosurg Focus 38(3):E6, 2015

21. Catton C, O'Sullivan B, Bell R, Laperriere N, Cummings B, Fornasier V, et al: Chordoma: long-term follow-up after radical photon irradiation. Radiother Oncol 41:67-72, 1996

22. Chambers PW, Schwinn CP: Chordoma. A clinicopathologic study of metastasis. Am J Clin Pathol 72:765-776, 1979

23. Chang EL, Shiu AS, Mendel E, Mathews LA, Mahajan A, Allen PK, et al: Phase I/II study of stereotactic body radiotherapy for spinal metastasis and its pattern of failure. $\mathbf{J}$ Neurosurg Spine 7:151-160, 2007

24. Cheng EY, Ozerdemoglu RA, Transfeldt EE, Thompson RC Jr: Lumbosacral chordoma. Prognostic factors and treatment. Spine (Phila Pa 1976) 24:1639-1645, 1999

25. Cohen AR, Wisoff JH, Allen JC, Epstein F: Malignant 
astrocytomas of the spinal cord. J Neurosurg 70:50-54, 1989

26. Coman DR, deLong RP: The role of the vertebral venous system in the metastasis of cancer to the spinal column; experiments with tumor-cell suspensions in rats and rabbits. Cancer 4:610-618, 1951

27. Constans JP, de Divitiis E, Donzelli R, Spaziante R, Meder JF, Haye C: Spinal metastases with neurological manifestations. Review of 600 cases. J Neurosurg 59:111-118, 1983

28. Constantini S, Miller DC, Allen JC, Rorke LB, Freed D, Epstein FJ: Radical excision of intramedullary spinal cord tumors: surgical morbidity and long-term follow-up evaluation in 164 children and young adults. J Neurosurg 93 (2 Suppl):183-193, 2000

29. Cooper PR: Outcome after operative treatment of intramedullary spinal cord tumors in adults: intermediate and long-term results in 51 patients. Neurosurgery 25:855-859, 1989

30. Cooper PR, Epstein F: Radical resection of intramedullary spinal cord tumors in adults. Recent experience in 29 patients. J Neurosurg 63:492-499, 1985

31. Cosgrove GR, Bertrand G, Fontaine S, Robitaille Y, Melanson D: Cavernous angiomas of the spinal cord. J Neurosurg 68:31-36, 1988

32. Cotten A, Dewatre F, Cortet B, Assaker R, Leblond D, Duquesnoy B, et al: Percutaneous vertebroplasty for osteolytic metastases and myeloma: effects of the percentage of lesion filling and the leakage of methyl methacrylate at clinical follow-up. Radiology 200:525-530, 1996

33. Cristante L, Herrmann HD: Surgical management of intramedullary spinal cord tumors: functional outcome and sources of morbidity. Neurosurgery 35:69-76, 1994

34. Cummings BJ, Hodson DI, Bush RS: Chordoma: the results of megavoltage radiation therapy. Int J Radiat Oncol Biol Phys 9:633-642, 1983

35. Dahlin DC, MacCarty CS: Chordoma. Cancer 5:11701178,1952

36. Dalbayrak S, Yaman O, Ozer AF: Minimally invasive approaches in metastatic spinal tumor surgery. Turk Neurosurg 25:357-361, 2015

37. De La Garza-Ramos R, Flores-Rodríguez JV, MartínezGutiérrez JC, Ruiz-Valls A, Caro-Osorio E: Current standing and frontiers of gene therapy for meningiomas. Neurosurg Focus 35(6):E4, 2013

38. Donnelly DJ, Abd-El-Barr MM, Lu Y: Minimally invasive muscle sparing posterior-only approach for lumbar circumferential decompression and stabilization to treat spine metastasis - technical report. World Neurosurg 84:14841490, 2015

39. Dudeney S, Lieberman IH, Reinhardt MK, Hussein M: Kyphoplasty in the treatment of osteolytic vertebral compression fractures as a result of multiple myeloma. J Clin Oncol 20:2382-2387, 2002

40. Dupuy DE, Hong R, Oliver B, Goldberg SN: Radiofrequency ablation of spinal tumors: temperature distribution in the spinal canal. AJR Am J Roentgenol 175:1263-1266, 2000

41. Edelson RN, Deck MD, Posner JB: Intramedullary spinal cord metastases. Clinical and radiographic findings in nine cases. Neurology 22:1222-1231, 1972

42. Ehni G, Love JG: Intraspinal lipomas: Report of cases; review of the literature, and clinical and pathologic study. Arch Neurol Psychiatry 53:1-28, 1945

43. Eimoto T, Yanaka M, Kurosawa M, Ikeya F: Plasma cell granuloma (inflammatory pseudotumor) of the spinal cord meninges: report of a case. Cancer 41:1929-1936, 1978

44. Epstein F, Epstein N: Surgical treatment of spinal cord astrocytomas of childhood. A series of 19 patients. J Neurosurg 57:685-689, 1982
45. Epstein FJ, Farmer JP, Freed D: Adult intramedullary astrocytomas of the spinal cord. J Neurosurg 77:355-359, 1992

46. Epstein FJ, Farmer JP, Freed D: Adult intramedullary spinal cord ependymomas: the result of surgery in 38 patients. J Neurosurg 79:204-209, 1993

47. Findlay GF: Adverse effects of the management of malignant spinal cord compression. J Neurol Neurosurg Psychiatry 47:761-768, 1984

48. Fourney DR, Schomer DF, Nader R, Chlan-Fourney J, Suki D, Ahrar K, et al: Percutaneous vertebroplasty and kyphoplasty for painful vertebral body fractures in cancer patients. J Neurosurg 98 (1 Suppl):21-30, 2003

49. Fox MW, Onofrio BM: The natural history and management of symptomatic and asymptomatic vertebral hemangiomas. J Neurosurg 78:36-45, 1993

50. Fuchs B, Dickey ID, Yaszemski MJ, Inwards CY, Sim FH: Operative management of sacral chordoma. J Bone Joint Surg Am 87:2211-2216, 2005

51. Galibert P, Deramond H, Rosat P, Le Gars D: [Preliminary note on the treatment of vertebral angioma by percutaneous acrylic vertebroplasty.] Neurochirurgie 33:166-168, 1987 (Fr)

52. Gandhi RH, German JW: Minimally invasive approach for the treatment of intradural spinal pathology. Neurosurg Focus 35(2):E5, 2013

53. Gerszten PC, Burton SA, Ozhasoglu C, Welch WC: Radiosurgery for spinal metastases: clinical experience in 500 cases from a single institution. Spine (Phila Pa 1976) 32:193-199, 2007

54. Gerszten PC, Ozhasoglu C, Burton SA, Vogel WJ, Atkins BA, Kalnicki S, et al: CyberKnife frameless stereotactic radiosurgery for spinal lesions: clinical experience in 125 cases. Neurosurgery 55:89-99, 2004

55. Gilbert RW, Kim JH, Posner JB: Epidural spinal cord compression from metastatic tumor: diagnosis and treatment. Ann Neurol 3:40-51, 1978

56. Gisvold SE: Editorial. Citation analysis and journal impact factors - is the tail wagging the dog? Acta Anaesthesiol Scand 43:971-973, 1999

57. Gokaslan ZL, York JE, Walsh GL, McCutcheon IE, Lang FF, Putnam JB Jr, et al: Transthoracic vertebrectomy for metastatic spinal tumors. J Neurosurg 89:599-609, 1998

58. Greenberg HS, Kim JH, Posner JB: Epidural spinal cord compression from metastatic tumor: results with a new treatment protocol. Ann Neurol 8:361-366, 1980

59. Guidetti B, Mercuri S, Vagnozzi R: Long-term results of the surgical treatment of 129 intramedullary spinal gliomas. J Neurosurg 54:323-330, 1981

60. Hamilton AJ, Lulu BA, Fosmire H, Stea B, Cassady JR: Preliminary clinical experience with linear accelerator-based spinal stereotactic radiosurgery. Neurosurgery 36:311-319, 1995

61. Harrington KD: Anterior cord decompression and spinal stabilization for patients with metastatic lesions of the spine. J Neurosurg 61:107-117, 1984

62. Harrington KD: Metastatic disease of the spine. J Bone Joint Surg Am 68:1110-1115, 1986

63. Harrington KD: The use of methylmethacrylate for vertebral-body replacement and anterior stabilization of pathological fracture-dislocations of the spine due to metastatic malignant disease. J Bone Joint Surg Am 63:36-46, 1981

64. Hennessey K, Afshar K, Macneily AE: The top 100 cited articles in urology. Can Urol Assoc J 3:293-302, 2009

65. Herman JM, McLone DG, Storrs BB, Dauser RC: Analysis of 153 patients with myelomeningocele or spinal lipoma reoperated upon for a tethered cord. Presentation, management and outcome. Pediatr Neurosurg 19:243-249, 1993

66. Higinbotham NL, Phillips RF, Farr HW, Hustu HO: 
Chordoma. Thirty-five-year study at Memorial Hospital. Cancer 20:1841-1850, 1967

67. Kavanagh RG, Kelly JC, Kelly PM, Moore DP: The 100 classic papers of pediatric orthopaedic surgery: a bibliometric analysis. J Bone Joint Surg Am 95:e134, 2013

68. Kernohan JW, Woltman HW, Adson AW: Intramedullary tumors of the spinal cord: A review of fifty-one cases, with an attempt at histologic classification. Arch Neurol Psychiatry 25:679-701, 1931

69. Klimo P Jr, Thompson CJ, Kestle JR, Schmidt MH: A meta-analysis of surgery versus conventional radiotherapy for the treatment of metastatic spinal epidural disease. Neuro Oncol 7:64-76, 2005

70. Klingler JH, Krüger MT, Kogias E, Brendecke SM, Hubbe U, Scheiwe C: Minimally invasive resection and vertebroplasty for an osteolytic C-1 metastasis of malignant meningioma: case report. J Neurosurg Spine [epub ahead of print July 17, 2015. DOI: 10.3171/2015.1.SPINE141041]

71. Laredo JD, Reizine D, Bard M, Merland JJ: Vertebral hemangiomas: radiologic evaluation. Radiology 161:183-189, 1986

72. Levy WJ Jr, Bay J, Dohn D: Spinal cord meningioma. J Neurosurg 57:804-812, 1982

73. Livingston KE, Perrin RG: The neurosurgical management of spinal metastases causing cord and cauda equina compression. J Neurosurg 49:839-843, 1978

74. Loblaw DA, Laperriere NJ: Emergency treatment of malignant extradural spinal cord compression: an evidence-based guideline. J Clin Oncol 16:1613-1624, 1998

75. Loblaw DA, Perry J, Chambers A, Laperriere NJ: Systematic review of the diagnosis and management of malignant extradural spinal cord compression: the Cancer Care Ontario Practice Guidelines Initiative's NeuroOncology Disease Site Group. J Clin Oncol 23:2028-2037, 2005

76. Loonen MP, Hage JJ, Kon M: Plastic Surgery Classics: characteristics of 50 top-cited articles in four Plastic Surgery Journals since 1946. Plast Reconstr Surg 121:320e-327e, 2008

77. Maranzano E, Latini P: Effectiveness of radiation therapy without surgery in metastatic spinal cord compression: final results from a prospective trial. Int J Radiat Oncol Biol Phys 32:959-967, 1995

78. McCormick PC, Torres R, Post KD, Stein BM: Intramedullary ependymoma of the spinal cord. J Neurosurg 72:523-532, 1990

79. McMaster ML, Goldstein AM, Bromley CM, Ishibe N, Parry DM: Chordoma: incidence and survival patterns in the United States, 1973-1995. Cancer Causes Control 12:1-11, 2001

80. Mima M, Demizu Y, Jin D, Hashimoto N, Takagi M, Terashima K, et al: Particle therapy using carbon ions or protons as a definitive therapy for patients with primary sacral chordoma. Br J Radiol 87:20130512, 2014

81. Miscusi M, Polli FM, Forcato S, Ricciardi L, Frati A, Cimatti M, et al: Comparison of minimally invasive surgery with standard open surgery for vertebral thoracic metastases causing acute myelopathy in patients with short- or midterm life expectancy: surgical technique and early clinical results. J Neurosurg Spine 22:518-525, 2015

82. Mullan S, Naunton R, Hekmat-Panah J, Vailati G: The use of an anterior approach to ventrally placed tumors in the foramen magnum and vertebral column. J Neurosurg 24:536-543, 1966

83. Murphy KJ, Deramond H: Percutaneous vertebroplasty in benign and malignant disease. Neuroimaging Clin $\mathbf{N}$ Am 10:535-545, 2000

84. Murray MR, Wang T, Schroeder GD, Hsu WK: The 100 most cited spine articles. Eur Spine J 21:2059-2069, 2012
85. O’Neill SC, Butler JS, McGoldrick N, O’Leary R, Synnott $\mathrm{K}$ : The 100 most cited papers in spinal deformity surgery: a bibliometric analysis. Orthop Rev (Pavia) 6:5584, 2014

86. Orecchia R, Vitolo V, Fiore MR, Fossati P, Iannalfi A, Vischioni B, et al: Proton beam radiotherapy: report of the first ten patients treated at the "Centro Nazionale di Adroterapia Oncologica (CNAO)" for skull base and spine tumours. Radiol Med (Torino) 119:277-282, 2014

87. Patchell RA, Tibbs PA, Regine WF, Payne R, Saris S, Kryscio RJ, et al: Direct decompressive surgical resection in the treatment of spinal cord compression caused by metastatic cancer: a randomised trial. Lancet 366:643-648, 2005

88. Ponce FA, Lozano AM: Highly cited works in neurosurgery. Part I: the 100 top-cited papers in neurosurgical journals. J Neurosurg 112:223-232, 2010

89. Rades D, Stalpers LJ, Veninga T, Schulte R, Hoskin PJ, Obralic N, et al: Evaluation of five radiation schedules and prognostic factors for metastatic spinal cord compression. J Clin Oncol 23:3366-3375, 2005

90. Rich TA, Schiller A, Suit HD, Mankin HJ: Clinical and pathologic review of 48 cases of chordoma. Cancer 56: $182-187,1985$

91. Robertson PL, Zeltzer PM, Boyett JM, Rorke LB, Allen JC, Geyer JR, et al: Survival and prognostic factors following radiation therapy and chemotherapy for ependymomas in children: a report of the Children's Cancer Group. J Neurosurg 88:695-703, 1998

92. Roy D, Hughes JP, Jones AS, Fenton JE: Citation analysis of otorhinolaryngology journals. J Laryngol Otol 116:363366,2002

93. Ryu S, Fang Yin F, Rock J, Zhu J, Chu A, Kagan E, et al: Image-guided and intensity-modulated radiosurgery for patients with spinal metastasis. Cancer 97:2013-2018, 2003

94. Ryu SI, Chang SD, Kim DH, Murphy MJ, Le QT, Martin DP, et al: Image-guided hypo-fractionated stereotactic radiosurgery to spinal lesions. Neurosurgery 49:838-846, 2001

95. Schebesch KM, Mueller S, Wendl C, Brawanski A, Riemenschneider MJ, Proescholdt M: Recurrence rates and functional outcome after resection of intrinsic intramedullary tumors. Clin Neurol Neurosurg 134:60-66, 2015

96. Seglen PO: Citation rates and journal impact factors are not suitable for evaluation of research. Acta Orthop Scand 69:224-229, 1998

97. Sen CN, Sekhar LN: An extreme lateral approach to intradural lesions of the cervical spine and foramen magnum. Neurosurgery 27:197-204, 1990

98. Solero CL, Fornari M, Giombini S, Lasio G, Oliveri G, Cimino C, et al: Spinal meningiomas: review of 174 operated cases. Neurosurgery 25:153-160, 1989

99. Sonneland PR, Scheithauer BW, Onofrio BM: Myxopapillary ependymoma. A clinicopathologic and immunocytochemical study of 77 cases. Cancer 56:883893,1985

100. Sørensen S, Børgesen SE, Rohde K, Rasmusson B, Bach F, Bøge-Rasmussen T, et al: Metastatic epidural spinal cord compression. Results of treatment and survival. Cancer 65:1502-1508, 1990

101. Spetzler RF, Detwiler PW, Riina HA, Porter RW: Modified classification of spinal cord vascular lesions. J Neurosurg 96 (2 Suppl):145-156, 2002

102. Stark RJ, Henson RA, Evans SJ: Spinal metastases. A retrospective survey from a general hospital. Brain 105:189213,1982

103. Steinberger J, Skovrlj B, Caridi JM, Cho SK: The top 100 classic papers in lumbar spine surgery. Spine (Phila Pa 1976) 40:740-747, 2015

104. Suit HD, Goitein M, Munzenrider J, Verhey L, Davis KR, 
Koehler A, et al: Definitive radiation therapy for chordoma and chondrosarcoma of base of skull and cervical spine. $\mathbf{J}$ Neurosurg 56:377-385, 1982

105. Sundaresan N, Digiacinto GV, Hughes JE, Cafferty M, Vallejo A: Treatment of neoplastic spinal cord compression: results of a prospective study. Neurosurgery 29:645-650, 1991

106. Sundaresan N, Galicich JH, Chu FC, Huvos AG: Spinal chordomas. J Neurosurg 50:312-319, 1979

107. Sundaresan N, Galicich JH, Lane JM, Bains MS, McCormack P: Treatment of neoplastic epidural cord compression by vertebral body resection and stabilization. $\mathbf{J}$ Neurosurg 63:676-684, 1985

108. Tokuhashi Y, Matsuzaki H, Oda H, Oshima M, Ryu J: A revised scoring system for preoperative evaluation of metastatic spine tumor prognosis. Spine (Phila Pa 1976) 30:2186-2191, 2005

109. Tokuhashi Y, Matsuzaki H, Toriyama S, Kawano H, Ohsaka S: Scoring system for the preoperative evaluation of metastatic spine tumor prognosis. Spine (Phila Pa 1976) 15:1110-1113, 1990

110. Tomita K, Kawahara N, Baba H, Tsuchiya H, Fujita T, Toribatake Y: Total en bloc spondylectomy. A new surgical technique for primary malignant vertebral tumors. Spine (Phila Pa 1976) 22:324-333, 1997

111. Tomita K, Kawahara N, Baba H, Tsuchiya H, Nagata S, Toribatake Y: Total en bloc spondylectomy for solitary spinal metastases. Int Orthop 18:291-298, 1994

112. Tomita K, Kawahara N, Kobayashi T, Yoshida A, Murakami H, Akamaru T: Surgical strategy for spinal metastases. Spine (Phila Pa 1976) 26:298-306, 2001

113. Volpe R, Mazabraud A: A clinicopathologic review of 25 cases of chordoma (a pleomorphic and metastasizing neoplasm). Am J Surg Pathol 7:161-170, 1983

114. Vrionis FD: Spinal oncology: an innovative field of its own? Cancer Contr 21:110-111, 2014

115. Vujovic S, Henderson S, Presneau N, Odell E, Jacques TS, Tirabosco R, et al: Brachyury, a crucial regulator of notochordal development, is a novel biomarker for chordomas. J Pathol 209: 157-165, 2006

116. Weigel B, Maghsudi M, Neumann C, Kretschmer R, Müller FJ, Nerlich M: Surgical management of symptomatic spinal metastases. Postoperative outcome and quality of life. Spine (Phila Pa 1976) 24:2240-2246, 1999

117. Weill A, Chiras J, Simon JM, Rose M, Sola-Martinez T, Enkaoua E: Spinal metastases: indications for and results of percutaneous injection of acrylic surgical cement.

Radiology 199:241-247, 1996
118. Weiss L: A metastasizing ependymoma of the cauda equina. Cancer 8:161-171, 1955

119. Wise JJ, Fischgrund JS, Herkowitz HN, Montgomery D, Kurz LT: Complication, survival rates, and risk factors of surgery for metastatic disease of the spine. Spine (Phila Pa 1976) 24:1943-1951, 1999

120. Wong DA, Fornasier VL, MacNab I: Spinal metastases: the obvious, the occult, and the impostors. Spine (Phila Pa 1976) 15:1-4, 1990

121. Yamada Y, Bilsky MH, Lovelock DM, Venkatraman ES, Toner S, Johnson J, et al: High-dose, single-fraction imageguided intensity-modulated radiotherapy for metastatic spinal lesions. Int J Radiat Oncol Biol Phys 71:484-490, 2008

122. York JE, Kaczaraj A, Abi-Said D, Fuller GN, Skibber JM, Janjan NA, et al: Sacral chordoma: 40-year experience at a major cancer center. Neurosurgery 44:74-80, 1999

123. Young RF, Post EM, King GA: Treatment of spinal epidural metastases. Randomized prospective comparison of laminectomy and radiotherapy. J Neurosurg 53:741-748, 1980

124. Yuh WT, Zachar CK, Barloon TJ, Sato Y, Sickels WJ, Hawes DR: Vertebral compression fractures: distinction between benign and malignant causes with MR imaging. Radiology 172:215-218, 1989

\section{Disclosures}

The authors report no conflict of interest concerning the materials or methods used in this study or the findings specified in this paper.

\section{Author Contributions}

Conception and design: Caro-Osorio, De la Garza-Ramos. Acquisition of data: De la Garza-Ramos, Benvenutti-Regato. Analysis and interpretation of data: all authors. Drafting the article: all authors. Critically revising the article: all authors. Reviewed submitted version of manuscript: Caro-Osorio. Approved the final version of the manuscript on behalf of all authors: Caro-Osorio. Statistical analysis: De la Garza-Ramos. Study supervision: CaroOsorio.

\section{Correspondence}

Enrique Caro-Osorio, Neurology and Neurosurgery Institute, Centro Médico Zambrano Hellion, TecSalud, Batallón de San Patricio 112,8th Fl., Monterrey 66278, Mexico. email: ecaro@ itesm.mx. 